\title{
Political Potency and the Impotency of European Sovereignism: Pandemic and Technocracy
}

\author{
Antonio Cantaro \\ Professor, Department of Constitutional Law, University of Urbino Carlo Bo, \\ Urbino, Italy \\ antonio.cantaro@uniurb.it
}

\begin{abstract}
The COVID-19 pandemic and the parallel economic and social crisis mark both a decline of neoliberal globalisation and a return of public intervention. As many have stated, the economic policy triptych of the past decades - the opening of markets, withdrawal of the state and privatisation - has substantially disappeared from the agendas of governments around the world. The 'political', in a sense, is back. But in what sense? Can we talk about a real paradigm shift? The return of the political that we are witnessing manifests itself in the permanence and persistence of the neoliberal anthropology of the masses, which is the legacy of globalism, of the Maastricht order and of its idea of civilisation (even more than its political economy dogmas).
\end{abstract}

\section{Keywords}

European sovereignism - political potency - neoliberal order - Maastricht Treaty pandemic - technocracy

It is written ... but, I tell you ...

MAX WEBER, ECONOMY AND SOCIETY 


\section{The Return of the Political?}

It has by now become almost a cliché the belief that the coviD-19 pandemic and the parallel economic and social crisis mark, on the one hand, a decline in neoliberal globalisation and, on the other, a return of public intervention and statehood. As many have stated, the economic policy triptych of the past decades - the opening of markets, withdrawal of the state, privatisation - has substantially disappeared from the agendas of governments around the world or at least is rapidly vanishing.

This belief is attributed to the Old Continent and labelled the crisis of the Maastricht order. Furthermore, in more recent times, the rise of unprecedented sovereignty claims under the tag Europe first' has emerged, ${ }^{1}$ imitating the Trumpian 'America first'.

European sovereignty brought emancipation from the autarchic impulses of nationalistic sovereignties. ${ }^{2}$ The shift involves both liberal Europeanism, the guardian of Maastricht orthodoxy, and anti-Europeanism, which had bet on the disintegration of the currency and of the EU. ${ }^{3}$

This striking display of the change of season in which we are immersed undoubtedly captures a fact. The 'political', in a sense, is back. But in what sense? Can we talk about a real shift of paradigm? ${ }^{4}$

Here responses may diverge and, often, legitimate desires and reasonable fears are confused with pragmatic reality, underestimating the weight of circumstance that caused investment in many of the adopted measures, in which it is difficult to find any explicit, basic strategic line beyond that of wanting to remedy immediate emergencies. Yet, great is the uncertainty under the sky; as always happens, in fact, in Gramscian 'interregnums'.

A common narrative prevails on the return of the Keynesian model of the state-protector, the state-interventionist, as well as the rise, on a supranational level, of a EU with more federal aspects, more solidarity, more maturity and more awareness of its mission in both the internal and global space.

1 J.-P. Darnis, 'Europe First', Aspenia 85 (2019), 132-40.

2 G. Saputo and J. Barbati, 'I federalisti alla prova della Conferenza sul Futuro dell'Europa', Eurobull, 7 March 2021, https://www.eurobull.it/i-federalisti-alla-prova-della-conferenza-sulfuturo-dell-europa?lang=fr (accessed 1 May 2021).

3 A. D'Attorre, L'Europa e il ritorno del politico. Diritto e sovranità nel processo di integrazione (Turin: Giappichelli, 2020).

4 F. Losurdo, 'Il governo europeo della crisi pandemica. Un cambio di paradigma?' in Dopo le crisi. Dialoghi sul futuro dell'Europa, eds. A. Somma and E. Mostacci (Rome: Rogas Editore, 2021), 132-45. 
The contribution that this representation offers to the understanding of the ongoing processes is certainly useful in interpreting the spirit of the times. However, this is a contribution that is far from exhaustive and thus brings the risk of leading to hasty and unilateral conclusions.

The specific form in which the political is making its comeback is the language of potency, which is one of the languages of politics but neither the only one nor necessarily the most desirable.

It is necessary to keep well in mind the normative and practical meaning that the rise of the language of potency has historically had. 'The State and/ or company', wrote Jean-François Lyotard half a century ago, 'the cantor of the post-modern condition - must abandon the idealist and humanist narratives of legitimation in order to justify the new goal: in the discourse of today's financial backers of research, the only credible goal is potency. Scientists, technicians, and instruments are purchased not to find truth, but to augment potency' 5

On the other hand, the specific reasons for the rise of the current language of potency must not be overlooked or underestimated. They should instead be taken very seriously.

The consensus which the logic and the language of potency enjoy today in Europe is largely due to the fascinating promise to stem the functionalist approach of the economic-legal integration process; ${ }^{6}$ to contain the hegemony of the neoliberal reasoning put forth by European technocracies over the last half-century; and to restrain the elevation of the means to the ends (after the era of the progressive technocracies of the 'golden age' of the welfare state [1945-75]), of statistical and numerical indicators into oracle deities, of expertise into a sacred foundation for government action. ${ }^{7}$

There is a risk that the subtle fascination of the emerging technocracies of the crisis - some have also termed them aristocracies $2.0^{8}$ - will result, in the medium and long term, in an additional and more radical depoliticisation

5 J. F. Lyotard, The Postmodern Condition: A Report on Knowledge (Minneapolis: University of Minnesota Press, 1984), 46.

6 A. Cantaro and F. Losurdo, 'L'integrazione europea dopo il Trattato di Lisbona', in Dal Trattato costituzionale al Trattato di Lisbona. Nuovi Studi sulla Costituzione europea, eds. A. Lucarelli and A. P. Griffi (Naples: ESI, 2009), 53-85.

7 L. Verzelloni, 'La vana ricerca della neutralità: razionalità ibride e bilanciamento di poteri in tempi di crisi e non', Federalismi.it 28 (2020), 197-211.

8 R. Abravanel, Aristocrazia 2.o. Una nuova élite per salvare l'Italia (Milan: Solferino, 2021). 
of our constitutional systems, ${ }^{9}$ the democracy from above that Gustavo Zagrebelsky referred to when Mario Draghi took office in Italy. ${ }^{10}$

The return of the political that we are witnessing manifests itself in the permanence and persistence of the neoliberal anthropology of the masses, ${ }^{11}$ which is the legacy of globalism, of the Maastricht order and of its idea of civilisation (even more than its dogmas on political economy). ${ }^{12}$

All of this further challenges our analytical and interpretative skills. For this reason, we shall start this discussion from the beginning, from the feelings and moods we have towards Europe.

\section{Technocracy of the Pandemic Crisis: Europe First}

An observation that feelings and moods change quite abruptly is widely shared. It happens at dawn when we wake up in the throes of euphoric optimism and at sunset when we slip into polemical scepticism.

A schizophrenic script has materialised several times during the pandemic crisis. In the last days of 2020, the arrival of the first doses of Pfizer-BioNTech vaccines and the organisation of joint ' $\mathrm{V}$-days' in the EU member states were hailed as symbolic, historic moments in the fight against the 'invisible enemy'. This was a touching proof of unity, in the words of Ursula von der Leyen, president of the Commission; the High Representative for Common Foreign and Security Policy never missed an opportunity to reiterate her solemn commitment 'to leave nobody behind and to make the vaccine a global public good'.

This idyllic picture didn't last long. If 'in times of normality, even the opportunism of power without imagination can be enough to make the shack work,',13 in extraordinary times everything becomes complicated. Indeed, since the first weeks of 2021, a large part of public opinion would point to the vaccination campaign as a symbol of European impotency, of the inefficiency and modesty

9 A. Algostino, 'Costituzionalismo e distopia nella pandemia di covid-19. Tra fonti dell'emergenza e (s)bilanciamento dei diritti', Costituzionalismo.it 1 (2021), 1-81

10 G. Zagrebelsky, 'La democrazia dall'alto', La Repubblica, 25 February 2021, 3.

11 A. Cantaro, 'Pandemia e scienza giuridica. In divergente accordo', Diritto e Società 2 (2020), $225-55$.

12 L. Paggi, 'Maastricht come civiltà. Frammenti di storia di una cultura oligarchica', in Rottamare Maastricht ed. A. Barba, M. D’Angellillo, S. Lehndorff, L. Pagi and A. Somma (Rome: DeriveApprodi, 2016), 25-47.

13 J. Habermas, Nella spirale tecnocratica. Un'arringa per la solidarietà europea (Rome and Bari: Laterza, 2014), 76 . 
of its technocracies. The president of the European Commission, rightly or wrongly, was the main target accused.

The list of things that were not working was long and merciless, and started with the contracts signed with the pharmaceutical companies, whose obscurity and secrecy would be seen as among the main reasons for the delays in procuring and administering vaccines.

There was an enormous gap between the narrative on the rational need to provide global answers to global problems and the discovery that neighbouring Britain, just divorced from the EU, and the small state of Israel had both dramatically outclassed on the vaccine distribution a giant with 27 member countries. The dirty linen was washed in public in the member states, with more than one considering that the time had come to go it alone and unilaterally remedy a 'flop' (vaccine nationalism), which could cause panic in a public increasingly concerned by the rapid spread of the variants of the virus.

This self-critical reflection explicitly evokes the need for a different approach from that of the past; it evokes the need for an increased and strengthened pragmatic crisis government.

With specific reference to the delays in vaccine production and procurement, diligent advisers have put forward arguments that apparently absolve EU institutions, substantially calling on the need to increase 'technocraticism' in European governance.

It has been argued that delays in procurement are not attributable to the incompetence and negligence of the Commission. It would not have been possible for the European contracts to have included clauses imposing penalties for delays. The pharmaceutical companies would not have accepted such clauses for products that, at the time of signing the contracts, they did not know would ever come to be and, if they did, might be difficult to produce on a large scale.

In short, the delay in the vaccination campaign could not be attributed to specific responsibilities of the Commission that had been neglected, but to a fundamental difference between the EU on the one hand, and the United States, Israel and the United Kingdom on the other in managing relations between the state and companies in achieving exceptional matters of common interest. It's about a difference between a legal approach, concerned with limiting the discretion of the public administration, and a pragmatic one that does not care. In being able to quickly acquire covid-19 vaccines, Pragmatic Countries (USA, UK, Israel) proved to be more effective than Legal Countries (EU member states). For Pragmatic Countries, what matters most is the final result, while for Legal Countries it is that resources be spent correctly. Therefore, the latter rely on complex procedures that reduce the risk of 
arbitrariness, but also increase the time required and therefore do not facilitate the achievement of the desired urgent purpose. ${ }^{14}$

In the meantime, the EU tried to escape the corner it was painted into with interventions, more or less contingent and urgent, whose effectiveness can be evaluated in the medium term and in the context of the many challenges (health, geo-economic, geopolitical) that the fight against the pandemic brings up daily.

Whatever the case may be, the idea of vaccine sovereignty on a European scale had gained unimaginable consensus and EU institutions and the main leaders of the member states prudently added it to their agendas and discussions. $^{15}$

Vaccine sovereignty is a particular category of a more general discourse on the need for a pragmatic crisis technocracy, which has grown significantly

14 F. Colasanti, 'Vaccini, Israele e Usa hanno battuto l'Europa: i Paesi pragmatici contro i giuridici', Corriere Della Sera, 6 May 2021, 6. The regulatory meaning of this questionable 'official defence' is clear. The Commission - it has been said - has proposed the creation of an agency, Hera, which will do some of the work that BARDA (the Biomedical Advanced Research and Development Authority) does in the US. But as long as the EU does not adhere to the pragmatic approach of the US, Europeans will not be able to effectively face the unprecedented challenges of the globalised world such as that of fighting epidemics and pandemics. The United States - it turns out - has achieved very remarkable goals in terms of scientific research in a way that we Europeans seem casual. They have put very high sums on the table; identified the objectives of the research; created ad hoc organisations to reach them; put in charge of these very high-level scientists/managers, giving them wide discretion on how to use the funds. And this also happened in the field of vaccines, where the US had an advantage in the work done for years by BARDA. Then, in early 2020, the US created Warp Speed headed by the general in charge of US Army logistics. The organisation has created a structure to manage and inoculate the thousands of volunteers needed for the trials, supported the system of companies in the production of vaccines and their filling. By early 2021 Warp Speed had spent $\$ 18$ billion; the EU 2.7 billion euros. The 'pragmatic' countries have relieved the manufacturers of any responsibility for the side effects of vaccines. The EU refused to take such a decision and, in the case of AstraZeneca, agreed to reimburse the firm only for the sums it was eventually ordered to pay by the courts.

15 On the supply front, Ursula von der Leyen announced during the European Council of 25 March 2021 legal actions against pharmaceutical companies that will not respect the commitments (the reference is to AstraZeneca), also hoping for 'reciprocity and proportionality' of the mechanism on exports (an invitation to Boris Johnson's government to export to Europe, as done by EU countries to the United Kingdom). The harshest words were those spoken by the Italian Prime Minister ('European citizens have the feeling of having been deceived by some pharmaceutical companies') for which 'staying put and not taking action would be difficult to explain', announcing full support for the tightening of the export mechanism. After all, Draghi had already blocked a batch of AstraZeneca vaccines, found in the Catalent plant in Anagni, 'applying' the European regulation on exports. 
in recent times. Although there are different 'variants' and interpretations of this discourse among supranational institutions and the leaders of member states, a common ethos runs through them, which sounds like this: European technocracies must learn the harsh language of the force of geopolitical and geo-economic interests. They must rely less on rules and more on the language of political potency. They must reconvert rootless technocracy, the so-called neoliberal technocracy that is shaped through the market (marktkonform) and that uses legal forms for its self-production, into a crisis technocracy. ${ }^{16}$ This is a technocracy that is able to go beyond the 'bureaucratic construct' of the EU, supported by a restricted political elite and legitimised in the public's eyes exclusively for the goals of well-being. A technocracy that takes as its qualifying telos the political potency, the 'grandeur' of the Old Continent: 'Europe first'.

\section{Geostrategic Mercantilism: Europe Potency}

The most popular term for the 'new' logic of political potency is European strategic autonomy. A formula long confined to the delimited space of discussion between experts on European defence and security policy, ${ }^{17}$ over the course of the last year it has entered the official vocabulary of the EU. It appears in the consolidated language of the EU amid the CovID-19 crisis, in the Joint Declaration of the members of the European Council of the 26 March 2020. The concern that the crisis could expose the industrial assets of the member states to predatory takeovers by third countries has induced European leaders to take the necessary measures to protect them.

Only a few months later, in the conclusions of the European Council in early October, strategic autonomy rises to the status of a fundamental goal of the EU. This goal ('the aim of our generation' as European Council President Charles Michel emphatically put it) can now be applied in a plurality of dimensions. ${ }^{18}$

These include the correction of strategic dependencies in the most sensitive industrial ecosystems (such as health), the space sector and the digital sector, as well as an active role in shaping a new system of world economic governance based on free trade and the role of the World Trade Organisation

16 Habermas, Nella spirale tecnocratica, 21.

17 N. Tocci, European Strategic Autonomy: What It Is, Why We Need It, How to Achieve It, Report (Rome: Istituto Affari Internazionali, 2021). In that sense see also European Parliamentary Research Service. On the path to strategic autonomy (September 2020).

18 F. Brugnoli, 'Alla ricerca dell'autonomia strategica europea', Centro Studi Sul Federalismo 198, 2 November $202 \mathrm{O}$. 
as arbiter, in which European companies may find greater protection against unfair and abusive practices. ${ }^{19}$

The words are, as usual, nuanced and prudent, but not sufficiently so to prevent them from revealing several flaws in the long-standing neoliberal economic orthodoxy.

There had already been warning signs. Indeed, the language of political potency is already, in some way, inscribed in the declaration made by Angela Merkel after the $\mathrm{G}_{7}$ summit in Taormina, Italy ('Europeans will have to take their destiny into their own hands'20); in the emphasis given at the beginning of her mandate by Ursula von der Leyen on the geopolitical nature of the European Commission; in the emphasis on autonomy/sovereignty contained in the Franco-German manifesto of February 2019 on industrial politics.

We have now gone far beyond mere petitions of principle, especially in those interpretations given by leaders such as Emmanuel Macron, ${ }^{21}$ at times with the silent consent of Berlin and at other times with the cautious but unequivocal consent of the champions of ordo-liberalism such as Wolfgang Schäuble.

The pandemic acted as a formidable accelerator of past tendencies, elevating European strategic autonomy and its language of political potency to a transversal paradigm, the interpreters of which are the EU's official institutional voices. The autonomy/independence deficit is the cause of the EU's inadequate, insufficient, stammering response to the pandemic, and it is only by filling this deficit that the EU can prepare itself to govern in response to the 'external shocks' that threaten Europe's role on a global level.

This principle, upheld by the most committed advocates of strategic autonomy (and its telos, Europe-potency), marks a clear break with neoliberal globalism, ${ }^{22}$ with the narrative of the global and European order - the Maastricht order - of the last 30 years. ${ }^{23}$

The pandemic will not spell out the end of globalisation. However, as has been stressed, it will question some of its ideological presuppositions, starting

19 N. Verola and M. Zaccagnino, 'Riflessioni sul concetto di autonomia strategica europea', Astrid Rassegna 17 (2020), 1-10.

20 https://www.politico.eu/article/angela-merkel-europe-cdu-must-take-its-fate-into-its-ownhands-elections-2017/ (accessed 1 May 2021).

21 'La doctrine Macron: une conversation avec le Président français', Le Grand Continent, 16 November 2020, $3-5$.

22 A. Cantaro, 'L'imperialismo del libero scambio. La costituzione economica europea nell'epoca del neo-mercantilismo globale', Federalismi.it 16 (2018), 1-12.

23 F. Losurdo, Lo Stato sociale condizionato. Stabilità e crescita nell'ordinamento costituzionale (Turin: Giappichelli, 2016). 
with the neoliberal triptych - the opening of markets, withdrawal of the state, privatisation - that had already been struggling before the health crisis.

The goal is clear and the motivation has been duly argued. Over the last few decades, globalisation has expanded thanks to ever more numerous and extensive value chains that, with the advancement of telecommunications and with the minimisation of production and transport costs, allow the de-structuring of the production process in several places. The digitisation of the economy has accentuated this trend to the advantage of China, especially in terms of the production of textiles and consumer electronics, and of India, in sectors such as pharmaceuticals. ${ }^{24}$ This expansion of value chains has fuelled the idea that supply problems no longer exist. The 'just-in-time' system has replaced the 'uneconomic' stockpiling system. Even the countries that had in the past been best prepared for pandemics lowered their guard.

The forecast is that, after the crisis, value chains will not disappear, but this dynamic will be partially questioned in three ways.

The first is a diversification of the supply of resources in the health sector. ${ }^{25}$ To be precise, limiting the rate of dependence on the exporting countries for essential products is not protectionism, but legitimate preparation for situations of extreme vulnerability towards foreign suppliers, with the awareness that globalisation is not made of fluid networks to which everyone has access, but rather of strategic nodes dominated by actors who can control them to their advantage in the event of a crisis. ${ }^{26}$

The second is the re-localisation of a certain number of activities, bringing them as close as possible to the places of consumption. The choice to shorten value chains also fits perfectly with the urgency of the fight against climate change. This will lead to an increase in the cost of products, shifting the balance between the need for safety and the search for the lowest cost for the

24 In Wuhan, where the pandemic was 'born', over 300 of the world's 500 largest companies are based.

25 'The extent of our dependence on China for the import of a number of products is enormous, especially for face masks and protective suits $(50 \%)$. In addition, $40 \%$ of the antibiotics imported from Germany, France and Italy comes from China, which ensures the production of $90 \%$ of the penicillin consumed in the world. Currently, not even a gram of paracetamol is produced in Europe. The creation of an inventory or of a strategic reserve of essential products would therefore allow the EU to guard against shortcomings and ensure their availability throughout Europe. The creation of the European rescEU program designed to respond to this risk by sharing means is a first step.' J. Borrel, 'Il mondo del dopo-Covid è già qui ..., IAI Papers 20 (2020), 4.

26 H. Farrell and A. Newman, 'Will the Coronavirus End Globalization as We Know It?' Foreign Affairs, 16 March 2020, 7. 
consumer, where the interests of the citizen must prevail over those of the consumer.

The third way is the use of alternative technological processes such as the diffusion of 3 D production or robots to contain the risks of relocation, a generalised protectionist impulse that would penalise Europe, the most dependent on the world trade area and the most affected by the economic slowdown.

The virtues of open markets and interdependence are not shelved forever, but the need for a new globalisation is highlighted to an unknown extent. The virus has left its mark. The epidemic, we recall, did not appear out of nowhere; it is instead the consequence of deforestation, of the loss of natural habitat, of the reduction of biodiversity, of the overexploitation of resources that brings wild species into contact with humans in densely populated areas. The crisis, as an indisputable hallmark of an overload ecosystem, requires a fight to preserve biodiversity against climate change and the multiplication of unsustainable economic, social and environmental imbalances.

Globalisation must change its face. The state must change its face. The stepping back of states has been at the heart of neoliberal ideology, but now it is a matter of restoring the strategic capacity to anticipate and prepare society to face collective challenges. Europe must change its face. The imperative of the single market has led to any form of protection being seen as an obstacle; this must be put aside.

The concept of soft power in the liberal international order ceases to represent a mandatory postulate and becomes an option (when and where it is possible). This is the shift from globalism to geostrategic mercantilism, which means responding with the language of political potency to others' mercantilism. Remember that while the EU plays 'according to international rules' and adopts stringent discipline to ensure equal conditions in a single market that is by now (almost) without barriers, its competitors do not hesitate 'to put on the weight-scale all the strength of the respective public authorities, in order to ensure a competitive advantage to their companies.' ${ }^{27} \mathrm{~A}$ mercantilist approach that lies on values-scale often different from those of Europe (qualitative, social and environmental standards of production), ${ }^{28}$ which forcefully put forth the issue of defending European companies in terms of security (technologic strategies), economically (supervision of market shares) and socially (defence of employment and welfare). ${ }^{29}$

27 Verola and Zaccagnino, 'Riflessioni sul concetto di autonomia strategica europea', 6-7.

28 Ibid.

29 Ibid. 
The hope, therefore, is for a radical paradigm change. With all due respect to the idea of Europe as a civil power predominant in the intellectual ambience of the post-1989 'end of history', ${ }^{30}$ now is the time for the advocates of strategic autonomy, of Europe as a political potency.

\section{The Sovereigntist Grammar of Independence}

The fascination with the language of political potency is growing. But there is a great danger that a potency without legitimate power will be resolved into mere force in a dominion without hegemony.

The 'apostles' of Europe as a political potency are advocates of a questionable grammar of sovereignty as independence of power that has begun to be forged in the heart of the various 'existential crises' that the EU has confronted since the beginning of the new millennium: the financial crisis (2008-12), the refugee crisis (2013-16), the crisis of the Islamist terrorism (2015-16) and the Brexit crisis (2016-19).

All these crises, like the pandemic, are summarily attributed to exclusively extra-European dynamics that have caused 'a descent of the EU to the global scale of potency'. ${ }^{31}$ The crises, however, have also increased awareness of the urgency of having an ethos adequate to the harsh language of geopolitics, the competition between leading civilisations involved in globalisation.

The solutions to the first crisis, the financial, reflects the sharpest and most articulated model of this emerging grammar of independence. It would be useful to briefly review its genealogy to assess its foundations, credibility and actuality, starting from an essential chronicle of the events in which the grammar of independence - the heart of European sovereignty - took shape.

The first of these events is widely known. In mid-2012, the eurozone was in great difficulty. The debt crisis was spreading to an increasing number of countries. Heavy winds of crisis were blowing in Greece. Euroscepticism was swelling in Britain.

On 26 June, Mario Draghi, who had been President of the European Central Bank (ЕСB) for about a year, held a conference in London and made an iconic pronouncement that changed the history of the crisis: 'Within its mandate,

30 B. de Giovanni, 'L'Europa, oggi', Studi Sull'integrazione Europea 7 (1) (2012), 9-23.

31 E. Letta, 'Dalla crisi più violenta, l'Europa potenza', in Il mondo dopo la fine del mondo (Rome and Bari: Laterza, 2020), 114-36. 
the ЕСв will preserve the euro, whatever it takes. And, believe me, it will be enough.' ${ }^{32}$

At the time, 'the Italian' did not enjoy unanimous consent. He had both admirers and detractors in Europe. However, he was not alone. The German Chancellor, Angela Merkel, had long been convinced that a deadly struggle with the markets was under way. 'Unconventional' tools would have to be used against a speculative attack that came from afar and that questioned the very existence of the monetary union.

That is what Draghi intended to do. He soon did so through the instrument of quantitative easing, which helped to reduce the spread of the debt crisis in many countries, starting with Italy. ${ }^{33}$

The second crisis took place eight years later, in 2020, in the midst of the so-called first wave of the pandemic. Draghi, now a former governor of the ECB, went back to London.

Interviewed by the Financial Times, he thought aloud about the unprecedented emergency and the policies needed to cope with it: 'Banks must rapidly lend funds at zero cost to companies prepared to save jobs. Since in this way they are becoming a vehicle for public policy, the capital they need to perform this task must be provided by the government in the form of state guarantees on all additional overdrafts or loans. ${ }^{34}$

This was the announcement of the second step of 'whatever it takes', the fight against COVID-19. Those who were expecting an army of neoliberal troops ready to take up arms remain disappointed. In a few months, the fundamental postulates of the Maastricht order melted like snow in the sun.

The 'whatever it takes' pronounced during the financial crisis by the ЕСв, the only, sovereign institution in the field of monetary policy, was now evoked as the general philosophy that member states, individually and collectively,

32 Speech by Mario Draghi, President of the European Central Bank, at the Global Investment Conference in London, 26 July 2012, https://www.ecb.europa.eu/press/key/date/2012/html/ sp120726.en.html.

33 'Quantitative easing', QE. The term appeared for the first time in the Italian media in 2006 with reference to the Japanese monetary policy and in 2012 with reference to the American monetary policy. Technically, 'creation and injection of liquidity into the system by central banks, through the purchase on the market of financial assets such as shares, bonds and government securities with the dual purpose of compensating for the dangerous decline in the number and consistency of loans granted to households and businesses and to eliminate toxic securities from the market'. In practice, a robust support from the European government bond market.

34 M. Draghi, 'Draghi: We Face a War Against Coronavirus and Must Mobilise Accordingly', Financial Times, 25 March 2020, 7. 
must resort to, in order to cope with the most destructive crisis since the end of World War II.

The shift from the sovereignty of a techno-structure in the field of monetary policy to a generalised sovereignty is fuelled by a generous narrative from the elites. At the end of the first decade of the 21st century, the EU had relied on the paradigm of moral hazard to interpret and deal with the financial crisis. The paradigm provided for limited forms of aid and solidarity and the promotion - if necessary, by 'commissioning' the governments of the member states - of best practices: sound public finances (austerity policies) and structural reforms (competitiveness policies). For better (for some countries) and for worse (for others), it did actually work like that.

In the pandemic era, however, another paradigm is prevailing. The paradigm of the symmetric and systemic crisis that demands that the dogmatic angsts of the EU as a mere community of stability be overcome by loosening budgetary constraints and by providing the EU with an autonomous fiscal capacity aimed at stabilising the European economy in the short term and at relaunching it in the medium term. The EU came to be viewed as a community of growth, and even beyond that as a community of sustainable development from an environmental and social point of view.

This is an important step from a constitutional point of view, which foreshadows a possible federal evolution of the EU. On the one hand, the sacred limits of the Stability Pact have been suspended and the provisions on competition have been waived (in particular, the prohibition of state aid); on the other hand, the unprecedented 'Next Generation EU' programme has been launched, both for the scale of supranational resources put on the table $\left(€_{75}\right.$ billion) and for the de facto creation of common debt securities.

Let's take a step back to 22 February 2019, one year before the outbreak of the pandemic.

Draghi gave a Lectio Magistralis on the conferral of an honorary degree in law by the University of Bologna. The audience of jurists was ideal to elevate his technocratic trademark 'whatever it takes' - to the general philosophy of a new political course of European life. True sovereignty, he observed with a fulminating Schmittian gesture, is given 'not in the power to make laws, as a legal definition of sovereignty requires, but in the best control of the events in order to respond to the basic needs of citizens'. In the globalised world, citizens' power to give themselves laws - the equal political right of citizens to give themselves a norm, to govern themselves, posited by recent jurists stuck in the theories of Rousseau and Kelsen - no longer ensures security and prosperity.

With one single blow, the idea of democratic sovereignty was demolished and the function of independent institutions was sanctified as being more 
credible in responding to the concrete needs of citizens by virtue of their flexibility (discretion) in pursuing objectives. True sovereignty is the political potency that is able to dominate and control events from the top, using expert, independent technical knowledge.

The idea of sovereignty as independence of power has no doctrinal intent. In the economy of Draghi's discourse, potency is the opposite of the state weakness ardently cultivated by neoliberals, which makes it necessary to rely on a common force. The loss of ineffective national sovereignty serves to gain a shared sovereignty.

Draghi highlighted that transnational cooperation involves only an apparent loss of national sovereignty. The nation-states are no longer able to exercise it, but it is the political potency of the EU that restores it to them in the most effective and advanced form of concrete benefits for their citizens. Thus, they would be acting through Europe to exercise that true sovereignty that is independence. Do not act through the nation-states, urged Draghi, where sovereignty is perhaps forever lost.

\section{Sovereignism in Action}

The topic of sovereignty as independence of power was developed with increased communicative and political effectiveness in the speech given by Draghi on the occasion of the confidence vote on his government in February 2021: 'Supporting this government means sharing the irreversibility of the choice of the euro. It means sharing the perspective of an increasingly integrated EU that reaches a common public budget capable of supporting countries in times of recession. Without Italy, there is no Europe. But outside Europe, there is less Italy. There is no sovereignty in solitude.'

These high-profile words were spoken two years after the Bologna speech, one year after the outbreak of the epidemic, in the midst of the unprecedented health, economic and social crisis. There is a need for geopolitical clarity to reassure external and internal interlocutors that the independence referred to is such because, once the sovereign hangover of the Trump era is over, Italy and Europe will be placed in the orbit of a wider political potency, namely the American imperial potency under the aegis of Joe Biden.

The Atlantic Alliance is the container in which the EU is located. Italy is a founding member of the EU and a protagonist of the alliance. This bond positions Italy in the reborn clash of civilisations between the West (the US, the EU and their allies) and the East (Russia and China), increasing its potency status. Otherwise, it is left alone ('there is no sovereignty in solitude'), there is 'the 
deception of what we are' (a semi-imperial power), 'the oblivion of what we have been' in the past (an intermediate pawn of the great game of power), and 'the negation of what we could be' (part of an imperial power). ${ }^{35}$

Draghi's canny, skilful, captivating speech in the domestic context in which was delivered also spoke (above all) to the outside, to the European technocracies, so that they embrace the horizon of sovereignty fully and without hesitation.

On this occasion as well, Draghi knew that his words would be well received. The issue was no longer just academic, appropriate for occasional speeches and destined to be archived in some bureaucratic conference on the future of the EU. The pandemic has hit the neoliberal order hard and before that, for four years, it had hit the 'hurricane' Trump.

Something has changed even in the perception in the pro-European salons. European sovereignty is no longer the taboo term it was at the beginning of the millennium, when, in the atmosphere of the 'end of history', influential intellectual élites discussed the magnificent and progressive destiny of Europe as a civil potency, and were pleased with an evanescent 'multilevel sovereignty' virtually everywhere and concretely nowhere. ${ }^{36}$

On the contrary, today is - and must be - the era of the politicisation of European technocracies, called to assume direct governmental responsibilities and exercise sovereign powers beyond the specific fields (such as monetary policy) in which they already did so. Thus there is a shift from policies to politics, overturning a widespread doctrine in the social sciences of recent decades.

A plastic representation of this politicisation was the widespread expectation that European technocracies would finally flex their muscles with big pharma, in the face of the delays in supplying vaccines, to assert the international political potency of the EU. Europe first in action, a path that took its first timid but concrete steps in the European Council of 25 March 2021 (see above).

Let me make a conclusive statement: a paradigm shift has occurred with regard to fiscal policy. The 'grundnorm' of the EU and of the member states is no longer the infamous policy of austerity, but instead 'whatever it takes'. The contingent reason is the need for a different positioning in the world economy and an acknowledgement of the vulnerability of the global value chains. The

35 https://www.repubblica.it/politica/2021/o2/17/news/fiducia_governo_draghi_discorso_ integrale-287965484/.

36 A. Cantaro, Europa sovrana. La Costituzione dell'Unione tra guerra e diritti (Bari: Dedalo, 2003). 
horizon is that of an intensification of the regionalisation processes of globalisation, a phase shift that requires the central focus to be placed on the issue of a more self-sufficient, balanced and sustainable internal growth.

This leads to a discussion of whether or not this paradigm shift is irreversible. Is 'whatever it takes' the equivalent on a European scale of the motto 'everything must change so that everything can remain the same'? ${ }^{37}$ Are we facing an escamotage directed to temporarily suspend the Maastricht order and then, once the storm is over, restore its foundations, principles and rules, and core logic?

There are certainly actors that feed this consideration. However, 'whatever it takes' cannot be dismissed as yet another attempt to 'buy time', as postulated in one interpretation of the integration process, made famous by a refined theory. ${ }^{38}$ Something has changed. The horizon of European sovereignty is no longer the taboo subject it was in the era of Europe as a civil potency, as the only possible and legitimate manifestation of the EU. ${ }^{39}$

The path is narrow and bumpy. But the direction of the journey is marked by some essential features.

From a geopolitical and geocultural point of view, there is a renewed declaration of faith in belonging/dependence to a wider political potency, competing with the emerging empires of the multipolar world. The absoluteness of strategic autonomy is relativised on the horizon of a new cold war between the West and the non-West: Atlantism.

From a constitutional point of view, this is the sovereignism of the elites. Democracy from above, as Gustavo Zagrebelsky 'generously' called it with reference to the rise to the premiership of the former governor of the $\mathrm{ECB},{ }^{40}$ is the culmination of a longer-term tendency to elevate the technocratic reason to full-scale government. This tendency aspires to embrace the populist binary friend-enemy logic. The technocratic reason exalts the mystique of performance and uses its expertise to respond more efficiently and effectively to the daily problems of citizens and better satisfy their basic needs.

An implicit stigmatisation of the abstractness of politics and its vast distance from real life compared to the deontological proximity of technocracy to concrete problems. The expert, the technician, the competent is seen as a friend; the professional politician is seen as incompetent and therefore an

37 This refers to the famous book by Giuseppe Tommasi di Lampedusa, Il Gattopardo.

38 W. Streeck, Buying Time: The Delayed Crisis of Democratic Capitalism (London: Verso, 2017).

39 Cantaro, Europa sovrana.

40 Zagrebelsky, 'La democrazia dall'alto'. 
enemy. The lay citizen expects 'ability' and 'merit' to be placed at the centre of the public agenda: techno-populism.

It is difficult to say how strong European sovereignty in its techno-populist form may be. In many ways, we are still in the Gramscian interregnum in which the 'legal order of the existing social order' - the neoliberal order of Maastricht - has lost 'its grip and is unable to govern the crisis', while a new order - the postliberal order of the technocracy of the crisis - is 'still in its embryonic state, it has not yet fully formed or it is not corroborated enough to be able to be applied and implemented'41

This does not prevent us from seeing the limits of the sovereign narrative right away. Not only because of the resistance of some of the member states' governments, but above all because of the inherent deficiency of vision and ambition in the sovereign narrative that constitutes its most authentic sign. Its ontological impotence is masked by a geopolitical rhetoric of potency.

\section{The Art of the Impossible: Sovereign Europe}

In my book Sovereign Europe, published almost 20 years ago, I argued that one of the two dark sins from which the supranational integration project suffered was political minimalism, or the claim 'to make Europe a civil potency, a leading entity of the global order, without making it a political potency in the classical sense. ${ }^{42}$

I also argued that the other dark sin of the European project was legal maximalism, the other side of political minimalism: the ideological trust in the ability of normative proclamations (primacy of law and rights) and proceduralism (primacy of governance and policies) to act as a functional substitute for politics and democracy.

European sovereignism intends to put an end to the hope that sovereignty could outlive itself in the form of sovereignty in an objective sense in the form (that a large part of legal science was preaching in the past) of a civilised sovereignty, a sovereignty of the fundamental principles of values and rights of the legal traditions of the member countries that are incorporated into the treaties and in the case law of the European Court of Justice.

It is no longer acceptable, it is argued, for national sovereignties to become weaker, while there is no matching response by the collective sovereignty in

41 L. Castellani, L'ingranaggio del potere (Macerata: Liberilibri, 2020).

42 Cantaro, Europa sovrana, 17. 
an era in which the main actors of globalisation are intensifying, in an ever more evident and marked way, the profile of geopolitical and geo-economic potencies. If the EU does not cut this knot, then Europe is destined to become the only region in the world 'not governed either economically or politically', a simple 'space' in a world populated by powers. ${ }^{43}$

The project of crisis technocracy, which is expected to sustain the supranational integration process with sovereignty in a subjective sense, does match with what I advocated for in my aforementioned book. The external convergence cannot recompense the different horizon of meaning of the two discourses. The sovereignty evoked by the advocates of European strategic autonomy is not the sovereign Europe that I still continue to promote today. Sovereign Europe is not an ordinary geopolitical and geo-economic potency, but a qualified potency founded on legitimacy that is capable of transforming into an identity space and a community of destiny.

European sovereignty assumes that it is possible to build a potency in the absence of a political myth to support it. It involves the belief that the charm of potency in itself is sufficient to give life to a legitimate power, as if it were a board game, a surrender to the 'joyful' anguishes of geopolitics.

Politics is certainly the art of the possible. But can politics shrunk only to the art of the possible still be politics?

The final word on this must go to Max Weber: 'It is correct - if understood correctly - that politics which leads to success is always the "art of the possible". But it is no less true that the possible has very often been achieved only by aiming at the impossible that lies beyond it. ${ }^{\prime 4}$

This quid that goes beyond the possible is the meta-narratives of the political power - narratives that maintain a relationship with an idea of justice and truth, and establish an intimate and authentic emotional connection between rulers and ruled.

If potency cuts off any relationship with this quid, it becomes only an apology of itself, a micro-narration of potency.

On the contrary, the modern meta-narratives of political power - the nation-state, society, class, party - maintain a close relationship with the ideals of justice, truth and humanity, no matter the specific sense of these concepts to which each of them appealed.

43 J. P. Fitoussi, 'L'ambizione di un nuovo contratto sociale', in L'unità dell'Europa. Rapporto 2003 sull'integrazione europea, ed. G. Vacca (Bari: Dedalo, 2003), 54-80.

44 M. Weber, 'Il senso della avalutatività delle scienze sociologiche ed economiche', in M. Weber, Il metodo delle scienze storico-sociali (Turin: Einaudi, 1974), 570. 
When 'the house burns', as in the pandemic, it was the governed who rushed first to put out the fire. Today, however, some intellectuals denounce the so-called health dictatorship.

The end of all modern meta-narratives of political power that we hailed as the greatest liberation, was actually the greatest misfortune that could have happened to us. 'There is something terrible in the abandonment of the gods', noted a contemplative and perplexed Canetti at the end of the 1940s. ${ }^{45}$

Weber had already glimpsed the misery of the postmodern condition:

The world could one day be full of nothing more than the small teeth of a gear, small men clinging to small occupations that set into motion other, bigger ones. This asphyxiating bureaucracy leads to despair and the world may one day know nothing else but men of this mould: this evolution in which we are already entangled is such, and the big problem therefore is not how to endorse it and accelerate it, but the concern of how to oppose this mechanism in order to protect a piece of humanity from this dismemberment of the soul, from this absolute domination of a bureaucratic conception of life. ${ }^{46}$

This condition has by far become today's boring and neurotic state of normality. ${ }^{47}$ Postmodern technocracies constantly preach: be operative, quantifiable, or you will disappear. And don't think; after all, we don't think either.

Extreme 'pragmatism', a compelling invitation to divorce ourselves from all that is beyond appearance (the search for the true, the just, the immeasurable), to abandon ourselves to the wilderness of a new state of nature in which 'the great heroes, the great dangers, the great circumvention and the great ideals' are lost forever. ${ }^{48}$

The emerging technocracies of the crisis are betting on the muscular fascination of potency, a sort of new, functional substitute for the meta-narratives of the political power, a discourse that has short legs.

My prediction does not arise from an ideological aversion to technocratic reason. Those who feed it have forgotten that the technocracies of a large part

45 E. Canetti, La provincia dell'uomo (Milan: Adelphi, 1993), as quoted in F. Mattei, 'Sul paradigma dell'efficacia e dell'efficienza', in Sul paradigma dell'efficacia in educazione, ed. F. Mattei (Rome: Anicia, 2012), 11-51.

46 M. Weber, Il lavoro intellettuale come professione (Turin: Einaudi, 1948).

47 Cantaro, 'Pandemia e scienza giuridica'.

48 Lyotard, The Postmodern Condition. 
of the last century still had a positive relationship with the meta-narratives of their time, with the socialist state and with the welfare state.

Technocracies are born within an Enlightenment vision of the world ('progressive', 'emancipatory', 'democratic') in the context of a 'reading of history oriented towards the improvement of the material and cultural conditions' of the community, of a 'rational organisation of society' inspired by the values of 'social justice and freedom', concerned with guaranteeing the widest dissemination of rights and life chances. ${ }^{49}$

In this horizon, technocratic reason performs a gregarious function, similar to the Weberian bureaucratic rationality that indicates the most technically effective means to achieve the ends assigned externally by politics (by the representative powers of the popular will). That is, we are still within the context of a transparent distinction between the subjective and value sphere that belongs to politics (selection of ends), and an instrumental sphere (determination of means) that belongs to technocracy.

Since the 1970s, with the rise of neoliberal reason, this actio finium regundorum between technocratic rationality and political rationality has become highly problematic.

Neoliberal technocracies, unlike progressive technocracies, nurture an unconditional faith that the main conflicts of modernity (capital-labour, man-woman, imperial countries-provinces of the empire) are now in decline and that the current function of technology is to contribute to the liberation of the potential and creativity of the current capitalist mode of production instead of that of providing rational means to support a just social composition of conflicts and the emancipation of the lower classes ('equal opportunity' is at the heart of today's social discourse).

The technique increasingly assumes the face of impersonal devices for the solution of concrete, contingent problems: equipment, procedures, technologies that are more and more advanced and able to regulate daily, social and working lives in a neutral and objective way, until today's developments of digital platforms organised by increasingly 'intelligent' algorithms that allow you to avoid talking to real people and execute instructions given by an app (as the food delivery riders in big cities well know).

There is not longer even a government of technicians, but a government of technology, an 'automatic pilot' that exempts us from decisions both as individuals and as a community. The means and the ends are less and less

49 F. Antonelli, Tecnologia e democrazia. L'egemonia al tempo della società digitale (Rome: L'Asino D'oro, 2019). 
distinguishable: experts, technical committees, techno-bureaucracies, and administrative and scientific techno-structures are increasingly involved in decision-making procedures, called on to impersonally answer the question of what to do and to provide answers bound to follow the logic of the scientific method 'if ... then'.

Even when the autonomy of politics in the determination of ends is formally proclaimed, as may happen in the management of emergencies, the use of the scientific method and of rational means is proposed to reduce as much as possible the subjective dimension of politics, implicitly portrayed as irrational. This implies that, ideally, technocratic rationality in decision-making should completely replace political rationality. Or, as the micro-narrative of Europe as political potency postulates, it should rise to the rank of political rationality. Politicians will limit themselves to campaigning, writing on social media and going on television. Meanwhile, the new class of experts and professionals in various areas will take the decisions that matter.

We are witnessing an evolution beyond the centuries-old distinction between politics and administration, between political roles and technical roles, between professional Weberian politics as guardians of the general interest and scientists as guardians of the autonomy of knowledge and research. This evolution understandably concerns genuine democrats, but the only antidote is to rehabilitate politics as the art of the impossible.

On the grounds of the possible, there is not, and must not be, any competition for supremacy with scientists, technicians and experts. But a world governed by technocracies, orphaned by the horizon of the impossible, can only be more and more a world falling prey to an absolute domination of a bureaucratic conception of life.

'It is written ... but I tell you ....' This is the expected action from the professionals of politics, the most important skill to make Europe a community of destiny. There is no humanism, truth or justice without great politics. There is no sovereign Europe without the beneficial illusions of Leopardi and Pasolini. 